Erratum doi: 10.1007/s00376-013-0001-6

\title{
Erratum to: Characteristics, Processes, and Causes of the Spatio-temporal Variabilities of the East Asian Monsoon System
}

\author{
HUANG Ronghui* (黄荣辉), CHEN Jilong (陈际龙), WANG Lin (王 林), and LIN Zhongda (林中达) \\ Center for Monsoon System Research, Institute of Atmospheric Physics, \\ Chinese Academy of Sciences, Beijing 100190
}

Erratum to: Huang, R. H., J. L. Chen, L. Wang, and Z. D. Lin, 2012: Characteristics, processes, and causes of the spatio-temporal variabilities of the East Asian monsoon system. Adv. Atmos. Sci., 29(5), 910-942, doi: 10.1007/s00376-012-2015-x.

In the original version of this article, a sentence starting from the 8th line in the right column on page 920 is wrong. It should be "During 1978-1992, opposite anomaly distributions to those during 1958-1977 appeared in this region."

The online version of this original article can be found at http://dx.doi.org/10.1007/s00376-012-2015-x 